\title{
Magda Szabó: Finding Home in the Homeland in Post-1956 Hungary
}

\section{Abstract}

In Iza's Ballad, Magda Szabó writes about the lives of two doctors who meet and fall in love at university. "Don't get too involved with politics," experienced Antal warns a seemingly ingénue Iza. To which she responds: "Politics will be my life as long as I live." In this brief encounter, Szabó connects the predominant themes of her oeuvre: politics and life, or, to be more specific, Communism and the domestic. In its analysis of Iza's Ballad (1963), Katalin Street (1969), and The Door (1987), this article illustrates how Szabó's descriptions of the domestic convey the impact of Hungary's troubled political history on the concept of the home/homeland. The article illustrates the ways in which Szabó contrasts the relatively comfortable years of Goulash Communism with the hardship endured during WWII, under Rákosi, and during the 1956 Revolution, to convey the lasting effects of the Soviet occupation on the notion of home.

Keywords: Magda Szabó; Hungary; homeland; 1956 Revolution; Goulash Communism; János Kádár

\section{Introduction}

Magda Szabó may not be the most famous twentieth-century author for Hungarian readers, today, this case could be made for the Nobel Prize winner Imre Kertész or the inter-war poet Attila József. For international readers, however, Szabó is the 'Grande Dame' of Hungarian literature (Schandl). She has been hailed as Dezső Kosztolányi's literary heir (Battersby), and her novels have been compared to Harry Mulisch's The Assault (Martino 78), Philippe Sands's East West Street (Taylor), and Elena Ferrante's Neapolitan series (Zarin). As a testimony to her global popularity, her work 
has been translated into over forty-two languages, and her most well received novel, The Door, was adapted for István Szabó's 2012 film, starring Helen Mirren! ${ }^{[1]}$ Her international reputation began in a way that would be envied by any budding author. As Szabó explains in an interview that took place shortly before she died in 2007, "My novels found their way to Herman Hesse in MS, and he recommended me to the German publisher Insel" (Szabó in HLO). Szabó modestly omits Hesse's praise, urging readers to embrace her writing: "With Frau Szabó, you have caught a golden fish. Buy all of her novels, the ones she is writing and the ones she will write" (Hesse in Rooney). With such endorsement, it is surprising that Szabó remains a relatively little-known author in the Western European and anglophone literary marketplaces. This may be due to the fact that only six out of her over fifty published texts have been translated into English to date, most of which were completed relatively recently: The Fawn (Az őz) in 1963, Night of the Pig Killing ( Disznótor) in 1965, The Door (Az ajtó) in 1994 (re-translated in 2005), Iza's Ballad (Pilátus) in 2014, Katalin Street (Katalin utca) in 2017, and Abigail (Abigél) in 2020[2] Typical of her work, the novels discussed in this article (Iza's Ballad, Katalin Street, and The Door) reflect upon the most turbulent political moments of Szabó's life, starting with the Second World War, followed by the build-up to the 1956 Revolution, and ending with the years of Goulash Communism that tentatively started in 1956 and lasted until 1989. They all deal with the difficulties of waiting for old lives to resume or for new ones to begin amidst the political backdrop of twentieth century Hungary.

To a large extent, Szabó's writing was determined by the fraught political context of Hungary's troubled twentieth century. In a television interview from 1992 celebrating her seventy-fifth birthday, Szabó talks about being aware of the synergy between her life and the political outlook in Hungary:

everything that happened to me definitely played out in a historical period, that is between my birth and my eventual death. At the same time, Hungary was alive, not just me and my parents, my sibling and my friendship group, but Hungary was alive, even Europe was alive, even the five continents were alive, and I had to feel every tectonic movement produced by the world in my own little life accordingly. ("Boldog Születésnapot!")[] 
In the same breath, Szabó says that the highs and lows in Hungary's recent history were mirrored in her own life. With such a deeply felt connection to the politics of her country, and as the analysis of her texts will show, politics informed Szabó's writing. Living under state-controlled censorship required Szabó to remain silent and was a contributing factor as to why her literary fame began in West Germany, through Insel press, rather than in Hungary. Today, however, Szabó's popularity at home can be seen within Hungarian families, as around every Christmas Éva Zsurzs's 1978 television adaptation of the young adult novel Abigél (1970) enjoys a primetime slot on Magyar Televízió, enchanting young and old alike.$^{[4]}$

Szabó was born in Debrecen at the height of the First World War in 1917. Her father taught her Latin, German, English, and French, and she went on to read Latin and Hungarian philology and history at the István Tisza (now Lajos Kossuth) University of Debrecen, completing her doctorate on A Romaikori szépségápolás (The Cult of Beauty in the Roman Age) in 1940. Upon moving to Budapest in 1944, Szabó immediately became a member of the Újhold (New Moon) literary journal, and, in 1945, she began working at the Ministry of Education and Religion, where she met fellow Újhold members ${ }^{[5]}$ This group provided a community for young writers like Szabó, István Örkény, János Pilinszky, and Ágnes Nemes Nagy. By 1948, the Party censor silenced all but the conformists who took their cues from the journal of the Party-controlled Writer's Association, Irodalmi Újság [Literary Newspaper]. As the Soviets controlled religious activity and the education system in Hungary at this time, Szabó lost her position at the Ministry. Despite this, she managed to publish her first two books - Bárány [The Lamb] and Vissza az emberig [Return to Man] - in 1947 and 1949, respectively. ${ }^{[6]}$ These poetry collections that document the tragedy of war won Szabó the Baumgarten Prize in 1949. In the essay "Merre van elöre?" ["Where Do We Go from Here?"], Szabó recalls her generation's plight during the war, the retraction of her literary prize, and the importance of peaceful protest:

my generation, who stepped onto the circus floor in 1945, did not withstand, suffer, or run the gauntlet under ordinary circumstances. Then, at a young age, full of trampled ambition, shattered by the humiliation of remembering the Baumgarten Prize, which was left in my possession for an hour and a half and then withdrawn at the behest of Minister Révai, I would have replied without hesitation: if there is no other way out of that which we have to live through every day, let us 
search for direction through resistance, or even blood. '56 proved me right, and yet now I answer

to the contrary, at the moment a solution to our situation, no matter how much the situation, amorphous for the moment, hardens, is only possible without violence and blood, otherwise we are permanently finished. (Merszi Möszjö)

Szabó lay low from 1949 until 1958, teaching at a primary school in Budapest whilst "for ten years [her] writing career had been politically frozen" (5), as she puts it in The Door. In the interview from 2007 Szabó said of this time that

a part of this country conspired against letting us [writers of the Újhold group] make our voice heard. This did not surprise me, I was pretty well-informed about politics. I was the daughter of the one-time cultural councillor of the city of Debrecen. How could I have expected the new communist leadership to like me? I was not one of their ranks. Why would they want me to represent Hungarian literature? (Szabó in HLO)

Expressing her moral and political opposition to the Party-sanctioned journal and newspaper, Irodalmi Újság and Szabad Nép [Free People], Szabó was left with no choice but to remain silent during the Rákosi years.

From 1945 until 1953, Mátyás Rákosi, backed by the occupying power and with the ÁVH (his secret police formally known as the State Protection Authority, or, Államvédelmi Hatóság), presided over what can only be described as a reign of terror ${ }^{[7]}$ Persistent threat of violence, arrests, forced labour, and torture enabled the Hungarian Communist Party (HCP) to establish a stranglehold on the political system that would not be loosened for many years to come ${ }^{[8]}$ It wasn't until Imre Nagy's appointment to Prime Minister on 4 July 1953 and his implementation of 'The New Course' that a degree of intellectual freedom was restored, stimulating the resumption of writing in the Magyarok (Hungarians, another dissident journal) and Újhold circles. Szabó later writes in "A minister neve" [The Name of the Minister] that when living under Rákosi, who, with his second-in-command, Ernő Gerő, retained a high degree of control during Nagy's premiership, she "felt that the nation's indignation will have to break out once, the country was steaming with repressed emotion, then what happened, happened, and our undertaking was lined with thousands of graves" (Merszi Möszjő trans. Váradi). Though this article does not focus on the Rákosi years, 
an overview of Szabó's experiences during this period is necessary because this era is redolent in the memories and fractured relationships Szabó's characters are at pains to heal, preventing unrestrained enjoyment of the relatively prosperous Goulash Communism years. Importantly for Szabó, writers began to see their works published again and Samizdat (dissident literature) become more widespread after the revolution's partial success in seeing the gradual easing of censorship. On 2 November 1956, Gyula Illyés's poem “Egy mondat a zsarnokságról” (“One Sentence on Tyranny"), an evocation and indictment of the Rákosi years, was finally published in Irodalmi Újság. Two years later, Szabó saw her first novel Freskó [Fresco] published[9] In her comments on Fresco, written during the years leading up to the revolution when the suppression of Rákosi's regime was at its worst, Szabó stresses the necessity for discretion:

Do you think I could possibly have told them that I am writing a novel about a painter who simply chooses a subject matter to work on instead of obeying what the newspapers tell her to do? If you ever read Fresco, you know that by the standards of that age my Annuska is a "terrible" character, functioning, as she does, in a rather unconventional way. No, I did not want to make it known what I was working on, because it might have brought danger on other people. (Szabó in HLO)

No doubt as a result of her own experience, Szabó's characters face oppression, surveillance, and threat from political figures who take the form of soldiers, informants, and propagandists. Szabó's skill lies in her ability to draw an invisible line between politics and storytelling. When János Háy asked about how Szabó's ideological beliefs surface in her novels, she answered:

A writer must never be involved in politics in the same way as a politician. These are two totally separate things .... A writer doesn't necessarily need to die for the sake of truth, but they must serve it at all costs. This is what all honourable writers do. (Szabó and Háy)

Through her novels, Szabó serves many truths about Hungary's recent history. Her most searing truth can be gleaned from the novels published when state censorship over literature slackened during János Kádár's leadership, a period lasting from 1956 until 1989, referred to by the sobriquets "Goulash Communism" or "Refrigerator Socialism." Under Kádár, Hungary began to ease itself out of the iron clenched fist in which the Soviets had previously held it; a time referred to 
as the Hungarian Thaw. In 1960, he issued a partial amnesty for political prisoners, banned the use of torture, abolished the practice of arbitrary internal deportation, and relaxed censorship on creative activity. In January 1962, the Party daily newspaper Népszabaság [People's Freedom] quoted Kádár in what became the mantra of the Kádár era: "Whereas the Rákosi-ites used to say: 'He who is not with us is against us,' we say: 'Those who are not against us, are with us'” (Cartledge 469). From this point on, Hungary enjoyed relative prosperity with its "pseudocommunism," becoming the "happiest barrack," as it was called, of the Soviet satellite states. ${ }^{[10]}$ In the following two decades, Hungarian lifestyle changed markedly. The increased commercialism and consumer-driven way of life was evident in the advertisements included in the periodical Magyarország (Hungary). Heino Nyyssönen states that in 1964 Magyarország "forecast an optimistic future by advertising a 'television to every house," adding that "[a] new apartment, a private car or small cottage at lake Balaton were the next goals of goulash communism" (162). As the standard of living gradually increased throughout the 1970s, by 1980 Hungarians had enjoyed a decade of good food and well stocked kitchens. As the historian and British Ambassador to Hungary from 1980 to 1993, Bryan Cartledge, remarks: "[l]iving standards had been rising steadily for a number of years and most families had acquired - albeit at a high price relative to wage levels - the basic symbols of material well-being: a refrigerator, a washing machine and a television set" (479). Sensitive to societal shifts, in Iza's Ballad Szabó describes an elderly woman's surprise at the "plastic tablecloths, various kinds of spray, nylon stockings, washing machines and buckets" ( Iza's Ballad 70) in a general store. With such descriptions of how characters react to commercialized culture, reflected in the increasing number of mod-cons to be found in the new apartments of the country's capital, Szabó literature acts as a barometer that measures the emotional impact of this new feeling of prosperity for people of her generation. As Veronika Schandl states, and as the analysis of Iza's Ballad below illustrates, "Szabó's oeuvre reflects a clear dissident voice that favors a bourgeois value system, something that was frowned upon during the years of Communism." As well as increased travel allowances and a nine-to-five working week, by 1987 Budapest had become the first city of the Eastern bloc countries to open a McDonald's fast-food restaurant, signaling its acceptance of globalization, consumerism, and capitalist business models. On the flip side, in 1982 the Hungarian economy was again teetering 
on the edge of collapse due to the increasing price of goods and "people who decade after decade had robbed the country of all credit" (The Door 107). Significant inflation meant that Hungarians struggled to keep up with the Joneses and needed to work several jobs to maintain their standard of living ${ }^{[11]}$ This situation was encapsulated in the saying that Hungarians "paid Swedish taxes on Ethiopian wages."

A similar parallel of outwardly perceived progress overshadowing significant drawbacks can be seen in the administering of new creative freedoms. For example, in an attempt to glean an informed understanding of Eastern Europe in relation to the western world and to strengthen ties between East and West, Hungarians voiced their desire for cultural exchange and international cooperation. Hungarian workers, academics, and laypersons sent letters of thanks to those who sent them books from abroad. Alfred Reisch quotes a recipient of an English dictionary expressing his gratitude: "every material gives a connection between two countries. I hope [there] will come such a time when we also can contribute to your cultural life" (Reisch 400). Whilst this letter shows promise it also reveals the restrictions to intellectual freedom and development that were still in place under Kádár. The main obstacle to Hungarians purchasing anglophone literature during the 1960s was financial. As one female teacher wrote on 15 January 1969: “As a 'lonely teacher' [of] English in a huge sea of Slav languages, I cannot get use of any English book, for there is some deep monetary obstacle [sic] which completely prevents me [from] purchasing any of them" (Reisch 413). Though disheartening, these letters also evidence the steady progress that Hungary was making towards encouraging and facilitating knowledge of, and, by implication, engagement with the West. This progress was administered by Kádár's right hand man and Minister of Culture, György Aczél.

In a move towards granting a degree of freedom of expression, Aczél monitored cultural output according to his 'Three T's' systemization: támogatott, türt, tiltott (promoted, permitted, prohibited). Under his stipulation that artistic works could be sanctioned if they were "ideologically debatable and more or less in opposition to Marxism or socialist realism, as long as they [possessed] humanistic value and [were] not politically hostile" (Cartledge 482), several leading poets including Illyés as well as Pilinszky and Nemes Nagy from Újhold published some of their most important work during the 1960s. With Iza's Ballad and Katalin Street published in 1963 and 1969. 
respectively, Szabó's work can be added to this list. The Door's much more direct engagement with Hungary's political situation (it includes a chapter-long discussion of the protagonist's distrust of politicians under the heading "Politics") is reflected in its later publication date and the increased creative freedom of the 1980s, as opposed to that of the 1960s. This is not to say that The Door is outspoken in its political ideology. It is worth remembering that as late as 1988 , the HCP led by Károly Grósz prohibited a commemorative procession to memorialize the events of 23 October 1956 (see Cox 1). Only since 1989, following the ruling Communist leadership's revision of the official view of 1956, have researchers in Hungary been able to openly discuss the events of 1956 as a revolution. The Door was published two years prior to this sanction, and though in comparison to Szabó's earlier novels it speaks openly about political history, a degree of cautiousness can still be felt in the exchanges between its two protagonists. With this in mind, Szabó examines the intersections of fascism and communism, loyalty and betrayal, family and solitariness with a degree of familiarity and understatedness that balances her need to speak out with an awareness that the traces of censorship have not yet faded. As such, her novels are testaments to the human spirit in the wake of occupation. As the analysis of the Goulash Communism years in Iza's Ballad, Katalin Street, and The Door demonstrate, Szabó's work asks searching questions about the meaning of home during a time when the concept of home itself is under unmatched strain from outside forces.

\section{Iza's Ballad}

Originally published as Pilátus, referring to Pontius Pilate, Iza's Ballad, as it is known in George Szirtes's English language translation, is about an elderly woman, Ettie Szőcs, who struggles to adjust to the fast-paced lifestyle of the city when she moves to Budapest to live with her daughter, Iza, after her husband dies. Iza's Ballad explores the impact of grief on Ettie and Iza, focusing on the effects it has on the central relationship of the novel, that between mother and daughter. The generations end with Iza, who, despite being married in her youth and having a long-term partner during the time of the novel, does not have a child. Iza is a strong-willed doctor who was not afraid to "run around bearing arms or delivering illegal leaflets" (Iza's Ballad 302) in her youth. For Szabó, not having children was a political decision, one which she made with fellow Újhold members so 
that there could be no bartering power for authorities to use against them (Szabó in HLO). During her televised interview Szabó confesses to the pain she feels at never becoming a mother, explaining that when she became a "slave" under the Soviet regime she decided: "I will not give birth to a slave" ("Boldog Születésnapot!"). For Iza, as for Szabó, politics dictates the shape and meaning of home and family. Thus, in its portrayal of two women from two generations, Iza's Ballad depicts the transformation of a women's place in society from demure housewife to independent professional. As Kathleen Rooney suggests, Iza and Ettie "have the best of intentions but can't escape the political and technological circumstances of their historical moment." By contrasting the lives of women from two generations, Szabó explores themes of family and belonging during the Second World War (when Iza and her ex-husband, Antal, were at university) and during the years of Refrigerator Socialism (when the novel is set). As the weight of political oppression and long-time suffering plays out in Ettie's distrust of the people she meets and knows in the novel - Iza and her boyfriend Domokos, the housemaid Teréz, Antal, and her old friend Gica - Szabó highlights how Ettie's foibles and fears shape and are shaped by the domestic and political environment in which she finds herself.

When Iza arranges for Ettie to live with her in Budapest, Ettie struggles to leave behind the comfort and familiarity of her home in the country. Instead of welcoming a new beginning, Ettie is left feeling alienated as she fails to acquaint herself with her new surroundings, waiting to be shown the smallest act of kindness. She is first shocked by the appearance of the houses in Dorozs that have "TV antennae" instead of "storks on top of the roofs" (Iza's Ballad 70). The reader then learns of Ettie's sense of displacement in Kádár era Budapest through the description of "overwhelming" crowds and startling "neon signs flashing on buildings" (85) that she sees as soon as she steps off the train. The contrast between the bustling metropolis and the slow-paced way of life to which she is accustomed is captured in Ettie's description of the city as an "alarming metropolis" (Iza's Ballad 85). Though the reader may expect Ettie's feelings of being overawed by the modernization that was sweeping across Hungary at this time to be calmed when settling into her new home with her daughter, this is simply not the case. Aside from the brightly upholstered armchair (86) and lack of space, Ettie immediately notices that "[t]here was no stove in the room, only a red-colored radiator, its controls shaped like slices of lemon, like a kind of laughing red mouth" (87). Ettie's 
personification of the nozzle of the radiator not only depicts her fear of modern technology, but also resembles Soviet iconography (red) and sentiment, which was felt to be bitter (lemon) and mocking (laughing), illustrating how Ettie's experiences are saturated in repressed fears of the Red Army and Rákosi's regime.

Ettie is unable to overcome her fears of new machinery, preferring to toast her bread in the fireplace and brew Turkish coffee on top of a portable paraffin stove. She is especially afraid of the refrigerator in Iza's apartment; a fear that prevents her from accepting the new luxuries Kádár's "Refrigerator Socialism" policies made available. Despite her best efforts in finding a way of "making the acquaintance of the refrigerator" by associating its mechanical humming noise with the purring of a cat (which bizarrely reminds her of her old rabbit, Captain), Ettie remains "frightened of all machines" (208). Her inability to get used to the increased commodification she sees around her is evident when she uses a wet rag to clean up the cherry soup she spills in the fridge without realizing, much to Iza's dismay, that she must first turn the electricity off. From this point on, Ettie avoids the fridge, choosing to store leftovers on the balcony, then, when told that people aren't "going from block to block begging for soup in 1960" (100), she throws the leftovers away. Ettie never manages to get used to the new way and pace of life and, from the very beginning, when she examines the electric toaster Iza has sent, Ettie decides that she "[doesn't] trust machines," or "things as basic as electricity" (3). Not only is Ettie unable to appreciate the changes that have taken place in Hungary since raising Iza during the 1930s and 1940s, but she is also unable to situate herself in the present. She remains, as she is repeatedly referred to as in the novel, "the old woman," living out of time and out of place, sitting in the armchair where she is left to "cry silently" (91). For Ettie, Hungary has become a strange land, one in which she tries to orient herself by taking endless tram journeys to the outskirts of the capital and back again, but one she cannot call home. When she finally returns to the country and to her old family house (she has kept her set of keys), Ettie is overcome by the fact that "the idea of home still existed" (248), but as she then realizes, home will forever remain an idea, not a reality. For Szabó, finding a home was also an abstract concept. She writes that after 1945 "the country is restless, moody, irritable, it feels like it can't find a home in its homeland, it does not feel its own amidst the desired security" ('A miniszter neve' in Merszi Möszjö trans. Váradi). Similarly, in her desire to return home, Ettie searches for 
both the countryside cottage where she raised Iza and for a sense of belonging in her homeland, one which she no longer feels a part of or understands, one that has made her silent and withdrawn, and one that leads to her inevitable departure.

\section{Katalin Street}

Katalin Street centers on three families living in Budapest whose lives become interconnected in the build-up to the Second World War. The families are forced to live together until 1968, when Kádár's "New Economic Mechanism" was set in motion and neighbouring Czechoslovakia was facing its revolution. The novel is divided into six significant dates: 1934, 1944, 1952, 1956, 1961, and 1968. It highlights the political impact of German and then Soviet occupied Hungary on the children of the three families: Bálint Biró (the army officer's son), Irén and Blanka Elekes (the retired headmaster's daughters), and Henriette Held (the Jewish family's daughter). As each chapter moves into a new political era, the fates and motives of the children are determined. For instance, by 1952, the Elekes, Biró, and Held houses have been "taken over by the state" (Katalin Street 164) and joined to create a social housing block: the furniture was "distributed among people dispossessed in the bombing' and they were 'required to take in a lodger." Henriette's tragic death as a young girl hiding from Nazi soldiers haunts the lives of and relationships between the other characters within the novel. Irén struggles to move beyond her ill-fated relationship with Bálint that began on the back of his attempted rape of her (159-60), and Bálint fails to re-assimilate into society having spent years in a Prisoner of War camp. Finally, Blanka's deportation during the height of post-War political unrest remains unresolved as the closing words of the novel plead "Bring Blanka home!" (267)!12]

True to memory, these events are not told linearly. Despite Szabó's broadly chronological structure, the novel ricochets between different times and narratives giving the reader the same sense of spatiotemporal displacement as that experienced by the characters who each recall scenes from their chequered past from different perspectives. Through this layering of narratives, Szabó reopens in her reader what Cartledge describes as the "deep scars, which still from time to time disfigure Hungary's public life and the private lives of her citizens" (507). Moreover, the novel's alinearity creates an atmosphere of foreboding that mirrors Kádár's post-56 political 
agenda which issued to its citizens a combination of hope, disappointment, struggle, and reward in varying degrees. Szabó describes these turbulent times in her essay "Elveszett a báránykája" ["Lost Little Lamb"], which is worth quoting from extensively:

What happened to our deceived generation starting from the occupation, mockingly referred to as liberation, until today, is as much history as my departure in December 1944 and what happened next. The temporary accommodation in Pest had cardboard windows, in the ministry where I worked, a bomb-beaten, perilous building, we initially had no heating fuel, we ate once a day, and our hearts were full of hope and serenity: now all evil is really over, now there will be a real, democratic Hungary. The illusion lasted for three years, then Rákosi stepped forward, and what happened from then until the fall of communism is also only history. Amongst the accessories of deception, violence, torture, and marginalization, we tried to stay on our feet while they stole from us, and they asked that we say they're spreading signs of friendly love. During the time of the Rajk trial unaware nurseries demanded Rajk's head in the name of the future of children, and traces of the shameful help for Prague are still felt when tourists go that way. (Merszi Möszjö)

Unable to separate political history from her own history, Szabó vividly recalls the bombed buildings, hunger, threats, empty promises, indoctrination of the so-called Red-kerchiefed Pioneers (Communist youth) and feeling of guilt for not assisting Czechoslovakia during the Prague Spring of 1968. The impact of this turbulence endured by Szabó's generation surfaces towards the end of Katalin Street when Irén and Bálint talk about their misfortunes.

In this scene, Szabó blends personal history with that of the city as Irén compares her despair over her tragically unfulfilled love for Bálint with the statues that surround them. At this point Irén, who spent years waiting for Bálint's affection, is working as a successful teacher, and has married Pali (with whom she has a daughter, Kinga), and Bálint has returned from the countryside (where he was sent as a punishment for taking bribes from patients at the hospital in Budapest). It is 1961 and, after the tumultuous preceding decades, the dust is settling in the political and domestic spheres. Irén recalls how the thought that love has brought her more sadness than joy "was no less horrifying than the statues around us," adding: "[i]f I could I would have plucked it out like a splinter from under a fingernail" (Katalin Street 249). As it becomes impossible for Irén to separate the sense of being continuously overshadowed by foreboding statues of political statesmen from 
the personal feelings she holds for Bálint, her thoughts reveal how politics and love cannot be mutually exclusive. As a result, Irén suffers a double sense of suffering and subjection; she must live "in the concentrated unreality in which we were all struggling and drowning" (249). Despite the relative comfort she enjoys during the Kádár era, as this statement suggests, Irén is still reeling from the unavoidable impact the political arena has had on her domestic space. The exhaustion caused by this mixture of the personal and the political is then played out between Irén and Bálint:

So there we sat, in silence. Neither of us spoke the words we should have, and this time it was I and not Bálint who saw that whatever we did say would change nothing. I looked at the statues standing around us, those strange forms that were little more than blocks of stone piled on top of one another rather than carved, and I imagined them directing their eerie, unseeing gaze at us. Then I turned my head away. I had heard Bálint heave a sigh, or rather not a sigh but a yawn, a yawn not of boredom but of sheer exhaustion, and I suddenly realized that I wanted to yawn too. I was inexpressibly weary. It was like finding myself able to sit and rest at last after years, decades of being pursued and hunted down. (253)

On the one hand, this passage illustrates the shared realization that the relationship has ended. On the other hand, if read in a political context, it indicates that the same sense of being finally at peace is not possible. Firstly, the notion that "whatever we did say would change nothing" evokes the victimization of innocent citizens forced to face trial (as Bálint was earlier in the novel). Secondly, Irén's need to look away from the aesthetically vulgar "blocks of stone" that she feels are "directing their eerie, unseeing gaze" at them recalls the unnerving statues of Stalin, Lenin, Marx, Engels, Dimitrov, Ostapenko, and Béla Kun that stood in the streets of Budapest. Thirdly, Irén's inexpressible weariness after "decades of being pursued and hunted down" does not so much convey her tired love for Bálint but is most likely the result of the decades of suffering she has endured at the hands of the Germans, the Red Army, Rákosi and his ÁVH. It is only in 1961, after a lifetime spent waiting for the oppression and threats from the authorities of occupied Hungary to subside, that Irén can "sit and rest" with hope that the situation will improve. This hope, that she will move on from her upsetting personal and political past, is evoked in Irén's description of watching how their shadows "writhed on the pavement," "flitting along beside us in the strong sunlight" as "[t]wo vast blocks of stone stalked ahead" whose "shadows had neither eyes, nor hands, nor feet. 
They were just limbless trunks" (254). The statue that immediately comes to mind is the Stalin Monument, completed on 18 December 1951 and demolished on 23 October 1956. In most cases, the removal of effigies of Stalin was organized and executed from above (Khrushchev ordered the de-Stalinization of cities in 1956), however, in Hungary's case, iconoclastic action was taken from below. In his notes on the situation in Hungary for the Central Committee of the Communist Party of the Soviet Union Presidium Meeting with Satellite leaders on 24 October 1956, Jan Svoboda describes the destruction of the Stalin Monument as follows: "The bandits [revolutionaries] wanted to tear down the statue of Stalin. When they were unsuccessful in this task, they seized a welder's torch and cut the statue to pieces, and then disposed of the whole thing" (Csaba, Byrne, and Rainer eds. 225) ${ }^{[13]}$ Like Irén's description, all that was left of Stalin's statue were two boots, “just limbless trunks" (Katalin Street 254) whose shadow still lingered but whose threat had been diminished. As the scene ends with Irén and Bálint going their separate ways into an uncharted future, Szabó seems to be suggesting that a new horizon, albeit uncertain, also awaits Hungary; a theme she revisits in The Door.

\section{The Door}

Like Iza's Ballad, The Door explores how the introduction of Western ways of life into the Hungarian home has both an alienating and energizing effect on an older and younger woman. Unlike Iza's Ballad, the older woman (Emerence Szeredás) is outspoken, independent, and knows her own mind, and the younger woman (Magda) is a sensitive, happily married author. The Door, narrated by Magda, begins with a prologue that describes her recurring nightmare and confession that she killed Emerence, the impeccably clean and orderly maid she hired in order to dedicate adequate time to her writing. The events that lead to this confession take up the entire novel. Magda becomes intrigued by the hard-working Emerence when she learns that no one is permitted to cross the threshold of her fastidiously cleaned apartment, and the pair strike up an unlikely friendship. Emerence comforts Magda when her husband returns home from hospital, she looks after the dog Magda rescues (who she names Viola), and she talks to Magda about her troubling childhood in Nádori. Indeed, Emerence's past consists of horrors so extreme - the violent deaths of her lover, parents, and twin siblings; poverty and hunger; abuse from her relatives; and rape by 
Nazi and Russian soldiers - that they could never be completely buried. It is only fitting, then, that the big reveal of the novel exposes Emerence's quarters to be far from clean and orderly. When her door is finally broken open, Emerence is sitting half-paralyzed from a stroke in her own filth, unable to clean away the maggots and cockroaches that are feasting on rotten food and faeces. As with Iza's Ballad and Katalin Utca, Emerence has not managed to outrun her past as the extremity of her suffering is paralleled by the extremity of her ruin. Not even her obsessive cleaning with disinfectant has been able to permanently eradicate the lasting imprint of the politics of her homeland on her home. It is as if her protection of the Jewish family's little girl, Eva Grossman, during the Nazi occupation, the murder of her fiancé by a riotous mob who "tore him apart, like a loaf of bread" (The Door 102), her witness of show trials during the 1920s that ended in "the legs of the victims kick[ing] out in exactly the same way, no matter which colour [White or Red] had strung them up" (94), the sight of her dead cat strung up from the handle of the front door, and her role in hiding deserters, partisans, fleeing Germans, and illegal Communists each stain her inner sanctum and deface her home. As the narrator explains:

it was all around her - the Grossmans ...; first a flood of Germans; then Hungarian soldiers, who disappeared and were replaced by the Arrow Cross; and then when the Arrow Cross left the Russians moved in. Emerence had cooked for them, and washed for them, before the villa fell under state ownership and became an apartment block, as I knew it. (131)

Whilst the squalor behind Emerence's door evidences this fusion between domestic and political, private and public; the act of opening the door becomes a metaphor for leading the way towards recovery through the exposure of Hungary's repressed memories of suffering during the Second World War, Rákosi's reign of terror, and the prolonged Soviet occupation. Szabó's experiences of '56 were offset by a determination to document what she has seen and to use the act of writing as a way of working through the tragedy she was living with the knowledge that these words would one day be revealed. During the television interview she recalls slipping on blood when going out for bread, adding that in this moment she felt compelled to respond through writing: "my entire life I reacted to everything with letters" ("Boldog Születésnapot!"). If what lies beyond Emerence's door is Szabó's documentation of the nation's history, its opening and immediate stench marks her belief in the need to confront the fact that there is something rotten in the state of Hungary. After 
opening the first door, Magda opens a second door inside apartment which reveals an ornately furnished room. For Magda, the instant destruction of its contents due to woodworm recalls "images of the tank battle on the Hortobágy" (The Door 255).

As the second door reaches further back into Hungary's history, another layer of horror is unveiled: the Battle of Debrecen which lasted from 6 to 29 October 1944. As she equates the disintegration of the furnishings with the Second World War, Magda narrates: "I saw once again what I had seen as a girl, a herd of cattle machine-gunned by the Germans, the sky seemingly impaled on their horns, and the chair-covers, like the hides of those beasts, shredded into nothing" (255). Here, the Hungarian home and its furnishings have fused with Hungary's war-torn history. As both Magdas write of this fusion, the doors become metonymical of the act of writing as they store experiences of Hungary's past, and, in order to move forward, the doors must one day be opened so that Hungary's history can be recognized before it details (or furnishings) are eradicated.

By opening both doors, Szabó exposes Emerence's subconscious absorption of her country's past. As Magda says of Emerence: "She claimed no interest in politics and yet, by some mysterious everyday process, she had managed to absorb something of what we had all been through during those years after the war" (25). For Liam Mcllvanney, "Szabó is keen to engage with the national past, 'the years people don't talk about very much': the White Terror and the Red; the Second World War; the forsaking of the Hungarian Jews; the calamity of 1956. But she does this while retaining the perspective, the human scale, of her characters" (Mcllvanney). At once mythologically endowed with strength and charisma and yet heavily flawed, Emerence carries the weight of Hungary's past with an equal measure of forbearance and fallibility. Although throughout the novel she manages to keep up appearances and is widely respected in her local community (especially by the Lieutenant Colonel), somehow it is inevitable that she ultimately falls under the weight of her nation's history which she carries as her own personal burden. Yet, as Mcllvanney remarks, Szabó never loses sight of the "human scale" of her characters and, unlike Arthur Koestler's Darkness at Noon (1940) or Czesław Miłosz's The Captive Mind (1953), whose characters' learned speeches carry the author's political agenda, in The Door it is Emerence's ignorance of politics that offers the reader insights into Hungary's complex political history. As Emerence's nephew says to Magda: "She understands nothing of the modern world .... When I wanted to explain the importance of land 
reform to her, she slapped me and screamed that she wasn't interested in what happened in '45" (83-4). When Magda and Emerence grow closer, Magda, who, like Szabó, finds her work as a writer determined by politics, cannot fathom Emerence's disenchantment from the world around her. In the "Politics" chapter (104-115), Magda tells the reader that even though "a limitless horizon lay open" for Emerence after the Second World War, "she had no wish to cultivate or advance herself, or work for the collective good, whether by obeying directives or joining in campaigns" (106). For Emerence, "the word 'politics' was banned from her world." (106) Though Emerence confesses her disregard for intellectual pursuits equating writing with children playing (133), her distrust and skepticism of Party propaganda could be seen as a sign of wisdom rather than of ignorance. Similarly, Kádár's well-known disregard for intellectualism (no doubt because of his own limited schooling) was perhaps one of his greatest assets as he managed to mobilize mass support amongst the working classes ${ }^{[14]}$ Though Emerence seems like Kádár in one way, she is, in fact, the antithesis of the political elite and treats all politics with a heavy dose of skepticism. As she says about the radio broadcasts she hears from the apartments above the street: "They want peace. Do you believe that? I don't, because who then will buy the guns, and what pretext will they have for hanging and looting? And anyway, if there's never been world peace before, why should it happen now?"' (109). Emerence reinforces her refusal to engage with the widespread media broadcasts that were increasingly popular on television during the Kádár era when she rejects Magda's gift of a portable TV set from the Book Week event she attended in Frankfurt. Through her unwillingness to introduce a Western commodity into her home, Emerence rejects Magda's hope that "it might bring the wider world into the Forbidden City" (168), referring to both Emerence's locked abode and Hungary's closed borders. Then, in a passage that encapsulates Hungary's move away from Communism towards Capitalism during the Hungarian Thaw, Magda tells the reader how Emerence

looked on East and West equally, without bias or sympathy, declaring that there were sweepers and their bosses in America too; that Kennedy was one of the bosses, and a negro who hadn't yet made it into the circus but still travelled around performing non-stop must be a king among sweepers. (111) 
Perhaps referring to Martin Luther King (MLK), who made his "I have a dream speech" during Kennedy's presidency (JFK was assassinated in November 1963, three months after MLK made his speech), Emerence draws parallels between Hungary and America when she states that society is divided into those who sweep (in the USA, the African American population fighting against segregation; in Hungary, the people fighting against Soviet occupation) and those who do not sweep (in the USA, the ruling elite in Capitol Hill; in Hungary, the Soviets and the Hungarian Socialist Workers Party led by Kádár). As Magda goes on to explain:

In her view Horthy, Hitler, Rákosi and Charles IV were all exactly the same. The fact was that whoever happened to be in power gave the orders, and anyone giving orders, whoever it was, whenever, and whatever the order, did it in the name of some incomprehensible gobbledegook. Whoever was on top, however promising, and whether he was on top in her own interests or not, they were all the same, all oppressors. In Emerence's world there were two kinds of people, those who swept and those who didn't, and everything flowed from that. It made no difference under which slogans or flags they staged national holidays. There was no force that could overcome Emerence. (108)

For Emerence, each new leader brings a new regime that issues hardship and expects servitude.

[15] By exploring the impact of political rhetoric ("incomprehensible gobbledegook"), propaganda ("slogans or flags"), and a slew of fascist and socialist figures ("Horthy, Hitler, Rákosi and Charles IV"), in terms of a domestic chore (sweeping), Szabó relocates the political from the streets of Budapest into the small apartment of an old woman who habitually sweeps the street outside her front door as if in an act of defiance. For Szabó, the novel itself becomes an act of defiance as she gives voice to a history that has remained silenced. The destruction of Emerence's possessions is an ambiguous step towards this recovery as it signifies a move towards cleaner domestic policies and warns against the eradication of history. For Szabó, Hungary's future depends on the prioritisation of learnedness and literature over politics. In "A miniszter neve" she writes: "Culture is the prius, it comes first, and not politics, which is only a projection of the nation's culturedness" ( Merszi Möszjő trans. Váradi). The fact that Magda, the cultured novelist, feels she has killed Emerence, the anti-intellectual labourer who disregards literature to such an extent she cannot even recognise Pertőfi, becomes significant. Perhaps Emerence's death is, in a way, a mercy- 
killing and, like the horrors of Hungary's past, she too must turn to ashes in order for a new culturedriven Hungaria to rise.

\section{Conclusion}

As Szabó interweaves politics, creativity, and the domestic, her novels become politically motivated acts of breaking an enforced silence. Enikő Molnár Basa also recognises these themes in Szabó's work, stating that it focuses on the "decline of the order and the effect of societal changes in women" (Molnár Basa in Wilson, Schlueter, and Schlueter 472). As the narrator of The Door, who, as a prominent Hungarian writer bears a close resemblance to Szabó states: "it had become clear that if someone didn't take over the housekeeping there would be little chance of my publishing the work I'd produced in my years of silence, or finding a voice for anything new I might have to say" (The Door 5). Indeed, both Magdas had to wait for censorship restrictions to lift in order to publish in their homeland. To a large extent, Szabó's novels are about what it means to wait, with little or no hope, to "find a home in its homeland ... amidst the desired security" (Szabó "A minister neve" in Merszi Möszjö). Emerence waits for enough money to build her crypt for loved ones she has lost, Irén waits for Bálint to return her love, and Ettie waits to feel at home again. These hopes, of course, are never fulfilled. Yet, despite the propaganda, suffering, and threats, Szabó's characters continue to wait without any certainty that their wishes will be granted. Though temptations to relent and surrender to the controlling forces around them arise, they each, whether motivated by courage or fear, wait. When asked if she ever felt tempted to relent and "play a dirty game" to be "better rewarded" as a writer, Szabó's response conveys how her own determination to wait in both her personal and professional life was, and forever remains, an act of defiance:

You mean me? Listen, my great-great-grandfather was a galley slave! He was supposed to compromise, but he refused to - he let himself be sold onto a Spanish galley. Protestants have the power to wait. They have always had to wait, as long as they have been around. They try to improve things, and if they fail, they just wait around, but not compromise. (Szabó HLO) 


\section{Works Cited}

Battersby, Eileen, “Iza's Ballad (translation).” The Irish Times, 9 Aug. 2014, www.irishtimes.com/culture/books/iza-s-ballad-translation-1.1888276. Accessed 15 May 2020.

Békés, Csaba, Malcolm Byrne, and János M. Rainer, eds. The 1956 Hungarian Revolution: A History in Documents. Central European University Press, 2002.

“Boldog Születésnapot!" Szabó Magda 75 éves'. Directed by György Fehér, produced by Opus 34, M2, Magyar Televízió, 28 September 1992.

Cartledge, Bryan. The Will to Survive: A History of Hungary. 3rd ed., Hurst \& Co., 2011.

Cox, Terry. "Reconsidering the Hungarian Revolution of 1956." Hungary 1956 - Forty Years On, edited by Terry Cox. Frank Cass, 1997, pp. 1-14.

Gamboni, Dario, The Destruction of Art: Iconoclasm and Vandalism since the French Revolution. Reaktion Books, 1997.

Kabdebó, Lóránt. Az Újhold Költői. Megyei Könyvtár, 1988.

Martino, Andrew. "Katalin Street." World Literature Today, vol. 91, no. 6, 2017, pp. 78-79.

Mcllvanney, Liam. "That Time." London Review of Books, vol. 27, no. 24, 15 Dec. 2005, www.Irb.co.uk/the-paper/v27/n24/liam-mcilvanney/that-time. Accessed 15 May 2020.

Nyyssönen, Heino. "Salami Reconstructed: 'Goulash Communism' and Political Culture in Hungary." Repenser Le Dégel: Versions du socialisme, influences internationales et société, special issue of Cahiers du Monde russe, vol. 47, no. 1/2, 2006, pp. 153-72.

Reisch, Alfred A., "Letters from Hungary under Goulash Communism." Hot Books in the Cold War: The CIA-Funded Secret Western Book Distribution Program Behind the Iron Curtain. Central European University Press, 2013, pp. 399-437.

Rooney, Kathleen, “The 'Ballad' of Magda Szabó.” Chicago Tribune, 18 Oct. 2016, www.chicagotribune.com/entertainment/books/sc-books-1019-izas-ballad-magda-szabo20161018-story.html. Accessed 15 May 2020. 
Schandl, Veronika. "The Grande Dame: Magda Szabó: A Portrait.” Hungarian Literature Online (HLO), 24 Jan. 2020, hlo.hu/portrait/the-grande-dame-magda-szabo-a-portrait.html. Accessed 15 May 2020.

Schandl, Veronika. Iza's Ballad. Translated by George Szirtes. Vintage, 2014.

Schandl, Veronika. Katalin Street. Translated by Len Rix. Maclehose Press, 2017.

Schandl, Veronika. The Door. Translated by Len Rix. Vintage, 2017.

Szabó, Magda, and János Háy, “Magda Szabó: I Don’t Like Bearing Grudges: An Interview with Magda Szabó." Hungarian Literature Online (HLO), 8 Jan. 2007, hlo.hu/interview/i_don_t_like_bearing_grudges.html. Accessed 15 May 2020.

Taylor, Catherine. "Katalin Street Review: Magda Szabó's Piercing Exploration of the Effects of Severe Trauma." The Irish Times, 19 Jan. 2019, www.irishtimes.com/culture/books/katalin-streetreview-magda-szabó-s-piercing-exploration-of-the-effects-of-severe-trauma-1.3736852. Accessed 15 May 2020.

Wilson, Katharina, Paul Schlueter, and June Schlueter, eds. Women Writers of Great Britain and Europe: An Encyclopedia. Routledge, 2013.

Zarin, Cynthia. "The Hungarian Despair of Magda Szabó's The Door." The New Yorker, 29 Apr. 2016, www.newyorker.com/books/page-turner/magda-szabos-the-door. Accessed 15 May 2020. 
[1] Chantal Philippe's French translation of The Door won the Prix Femina Étranger in 2003. Katalin Street won the Prix Cévennes for Best European Novel in 2007. In 2020, Szabó's novel Pilátus was made into a film directed by Linda Dombrovszky.

[2] Katalin Róbert translated Szabó's short story Dreams of Pursuit for The lowa Review in 1976. Animal Lovers was also translated by Stephen Sass, appearing in The lowa Review in 1984. The children's stories Tell Sally and The Gift of the Wondrous Fig Tree were published in 1963 and 2008, respectively.

[3] All translations have been completed by Anna Váradi, to whom I owe a huge debt in the completion of this article.

[4] Abigél was ranked sixth out of the one hundred favourite books of all time in Hungary's version of the BBC's "The Big Read."

[5] For a study of the Újhold group, see: Kabdebó, Lóránt, Az Újhold költői. Békéscsaba: Megyei Könyvtár, 1988.

[6] When describing Újhold's decision to work underground during the Rákosi years, Szabó explains: "silence only means that one does not publish but does not mean that one does not create anything (“Boldog Születésnapot!").

[7] At a meeting of the Writer's Association in April 1956, the writer Sándor Lukácky referred to Rákosi as "a Judas whose hands are stained with blood" (Lukácky in Cartledge 440).

[8] As Bryan Cartledge explains: "[e]stimates of the number of victims of the reign of terror over which Rákosi presided between 1949 and 1953 vary, but it is certain that at least three-quarters of a million Hungarians were charged with offences against the state; of those found guilty - over half - over 200,000 underwent imprisonment, internment or forced labour. The death toll included not only some two thousand sentenced to execution but many more who failed to survive torture at the hands of the ÁVH or the privations of the camps" (425).

[9] Szabó published several works in the late 1950s, including Neszek [Sounds] in 1958 and Az őz (The Fawn) in 1959. She won the József Attila Prize in 1959 and in 1972. She won the Kossuth Prize in 1978 and the Tibor Déry award in 1996. 
[10] Despite an increase in the standard of living in Hungary under Kádár, Hungarians were still under oppressive rule. Keen to assert his control, one of Kádár's first moves as General Secretary was the formation of a "Revolutionary Home Guard Militia" (known as the pufajkások, after the padded jackets they wore) which relieved the Soviet units of their internal security duties by issuing control, snuffing out any dying embers of revolutionary spirit, and pronouncing loyalty to the Party.

[11] Hungary was bailed out from economic collapse by the World Bank and the International Monetary Fund in 1982.

[12] From the 4 November 1956, Hungarian refugees fled to the Austrian and Yugoslav frontiers laden with bags and handcarts full of personal affects. As Cartledge documents, "[b]y midDecember, over 200,500 Hungarians - 2 per cent of the nation's population - had sought refuge outside their country. They left behind them at least 2,700 who had lost their lives in the revolution, including 196 children under fourteen, and 27,000 wounded. Soviet casualties numbered 669 dead and 1,450 wounded - an indication of the ferocity of the Hungarian resistance" (458).

[13] When demolishing the statue, revolutionaries graffitied "W.C" on the left cheek and attached a sign around the neck that read: "Russians, if you take to your heels, please do not leave me behind" (see Gamboni 58-60).

[14] In 1956, he turned on a group of journalists, saying: "You imagine that you are an important, influential force in society. You are not: the working class is the only such force and you are like flies sitting on the yoke. It's the oxen, not you, who are pulling the cart, whatever you may think" (Cartledge 462).

[15] As Sándor Márai puts it: "[a] people that had already lived in servitude for so long seemed to know that their lot was not going to change: the old masters had left, and the new masters had arrived, and they would remain slaves as before" (Márai 31).

\section{cc) (i) () $९$}

Creative Commons Attribution-NonCommercial-NoDerivatives 4.0 International License 